\title{
Kejadian Rheumatoid Arthritis pada lansia di Poliklinik Bandar Lampung
}

\author{
Athaya Hafizhah ${ }^{1 *}$, Umi Romayati Keswara², Dhiny Easter Yanti ${ }^{3}$ \\ ${ }^{1}$ RSUD H. Abdul Manap Kota Jambi. *Email: thaya.fizha@gmail.com \\ 2Program Studi Diploma III Keperawatan Universitas Malahayati \\ ${ }^{3}$ Fakultas Kesehatan Masyarakat Universitas Malahayati
}

\begin{abstract}
Rheumatic disease in the elderly: Rheumatoid arthritis cases and non-rheumatoid arthritis controls

Background: Rheumatoid arthritis (RA) is an autoimmune disease that affects most people and the exact cause is unknown. Based on data from Bandar Lampung, RA ranks fourth in the profile of the top 10 diseases that have emerged since 2012. Although the cause is unknown, RA complications are very dangerous, ranging from joint deformities \& disabilities, internal organ damage, to death.

Purpose: To determine the factors associated with the incidence of rheumatoid arthritis in the elderly

Method: Quantitative research with a case control design. The study population was all elderly patients at Pertamina Bintang Amin Hospital. The samples used were 47 cases and 47 controls. Multivariate analysis using multiple logistic regression tests.

Results: It shows that there is no relationship between economic status ( $p$-value 0.062 ) and the incidence of RA at Pertamina Bintang Amin Hospital. There was a significant relationship between smoking ( $p$-value 0.042; OR 2.86), diet (p-value 0.013; OR 3.61), occupational (p-value 0.000; OR 6.80), and obesity (p-value. 0.017; OR 3.25) with RA.

Conclusion: The most dominant factor associated with the incidence of RA in the elderly is work $(O R 7,8)$. Workers at high risk are advised to use personal protective equipment while working and provide time for fun outdoor physical activity so as to reduce stress and help the absorption of vitamin D in the body more optimally.
\end{abstract}

\section{Keywords: Elderly; Rheumatoid arthritis; Obesity; Smoking; Economic status; Occupational}

Pendahuluan: Rheumatoid arthritis $(\mathrm{RA})$ merupakan penyakit autoimun yang paling sering terjadi di masyarakat dan belum diketahui secara pasti penyebabnya. Berdasarkan Data Kota Bandar Lampung, RA berada diurutan keempat dalam profil 10 penyakit terbesar yang muncul sejak tahun 2012. Meski penyebabnya belum diketahui, komplikasi RA sangat berbahaya, mulai dari deformitas sendi \& disabilitas, kerusakan organ-organ dalam, hingga kematian.

Tujuan: Mengetahui faktor-faktor yang berhubungan dengan kejadian rheumatoid arthritis pada lansia di poliklinik rawat jalan Rumah Sakit Pertamina Bintang Amin (RSPBA) Tahun 2019.

Metode : Penelitian kuantitatif dengan rancangan kasus control (case control). Populasi penelitian adalah seluruh pasien lansia di Rumah Sakit Pertamina Bintang Amin. Sampel yang digunakan sebanyak 47 kasus dan 47 kontrol. Analisis multivariat menggunakan uji regresi logistik ganda.

Hasil : Tidak ada hubungan antara status ekonomi (nilai $p$ 0,062) dengan kejadian RA di RSPBA. Ada hubungan yang signifikan antara merokok (nilai p 0,042 ; OR 2,86), diet (nilai p 0,013; OR 3,61), pekerjaan (nilai p 0,000; OR 6,80), dan obesitas (nilai p 0,017; OR 3,25) dengan kejadian RA.

Simpulan: Faktor yang paling dominan berhubungan dengan kejadian RA pada lansia di poliklinik rawat jalan RSPBA Tahun 2019 adalah pekerjaan (OR 7,8). Disarankan pekerja berisiko untuk menggunakan alat pelindung diri saat bekerja, dan menyediakan waktu melakukan aktifitas fisik di luar ruangan yang menyenangkan sehingga dapat mengurangi stress dan membantu penyerapan vit. D lebih maksimal.

Kata Kunci: Rheumatoid Arthritis; Lansia; Status ekonomi; Merokok; Pekerjaan; Obesitas 


\section{PENDAHULUAN}

Rheumatoid arthritis (RA) merupakan penyakit autoimun yang paling sering terjadi di masyarakat. Penyakit ini ditandai dengan peradangan pada lapisan sinovium sendi. Hal itu dapat menyebabkan kerusakan sendi jangka panjang, rasa sakit yang berkepanjangan, kehilangan fungsi dan kecacatan (Singh et al., 2015). Penyebab dari RA masih belum diketahui, ada yang menyebutkan faktor genetik dan faktor lingkungan dapat meningkatkan risiko penyakit RA (Firestein et al., 2017). Meskipun dapat menyerang dari segala usia, tingkat prevalensi meningkat secara progresif dengan onset puncak pada dekade kelima dan tingkat insiden lebih tinggi pada wanita dibandingkan pada pria. (Bykerk et al., 2012).

Di Indonesia, RA merupakan penyakit reumatik yang paling banyak ditemui dibandingkan kasus penyakit reumatik lainnya. Berdasarkan data Badan Kesehatan Dunia (WHO), penduduk yang mengalami gangguan $\mathrm{RA}$ di Indonesia tercatat $8.1 \%$ dari total penduduk. Poliklinik Reumatologi RSUPN Cipto Mangunkusumo Jakarta, pada tahun 2000 kasus baru Artritis Reumatoid merupakan 4,1\% dari seluruh kasus baru. Di poliklinik reumatologi RS Hasan Sadikin didapatkan 9\% dari seluruh kasus reumatik baru pada tahun 2000-2002 (Perhimpunan Reumatologi Indonesia, 2014).

Di Lampung sendiri, sesuai dengan data dari Dinas Kesehatan Provinsi Lampung, RA merupakan salah satu dari 10 penyakit terbesar sejak tahun 2011 dengan 17.671 kasus (5,24\%). Pada tahun 2017 kejadian RA sebanyak 147.070 (10,32\%). Data kota Bandar Lampung, RA berada diurutan keempat dalam profil 10 penyakit terbesar di Bandar Lampung yang muncul sejak tahun 2012 dengan $4,1 \%$ dari kasus baru dan meningkat pada tahun berikutnya, hingga pada tahun 2017 angka kejadian RA mencapai 9\% (Dinas Kesehatan Provinsi Lampung, 2016). Pada tahun 2018 di Rumah Sakit Pertamina Bintang Amin (RSPBA) dari keseluruhan lansia 891 yang mengalami RA sebanyak 72 lansia, terlihat peningkatan kejadian
RA setiap tahun dan menduduki peringkat ke 5 dari 10 penyakit terbanyak penderita rawat jalan.

Walaupun penyebab RA masih belum diketahui secara pasti, namun banyak faktor risiko yang dapat meningkatkan angka kejadian RA diantaranya adalah faktor genetik, usia lanjut, jenis kelamin perempuan, faktor sosial ekonomi, faktor hormonal, etnis, dan faktor lingkungan seperti merokok, infeksi, faktor diet, polutan, dan urbanisasi (Tobon et al.,2010).

Penelitian ini bertujuan untuk mengetahui faktor-faktor yang berhubungan dengan kejadian RA pada lansia di Poliklinik Rawat Jalan Rumah Sakit Bintang Amin Kota Bandar Lampung Tahun 2019.

\section{METODE PENELITIAN}

Jenis penelitian adalah penelitian kuantitatif dengan rancangan case control. Penelitian dilaksanakan pada bulan September 2019 dengan subyek penelitian sebanyak 47 kontrol dan 47 kasus yang sesuai dengan kriteria eksklusi (Kasus yang tidak terpantau oleh petugas, memiliki penyakit komplikasi, serta sudah pindah domisili) dan kriteria inklusi (Lansia mengalami sakit RA yang datang ke poliklinik, pasien Rumah Sakit Bintang Amin, bersedia menjadi responden, mampu berkomunikasi dengan baik secara tulisan dan lisan), untuk pasien kriteria inklusi responden kontrol adalah lansia penderita penyakit sendi selain RA yang datang ke poliklinik, bersedia menjadi responden, dan mampu berkomunikasi dengan baik secara tulisan dan lisan, kriteria eksklusi responden kontrol sama dengan responden kasus.

Penelitian ini menggunakan Accidental sampling sebagai teknik sampling. Data penelitian diperoleh dengan menggunakan kuesioner data demografi berisi 7 item (nama, jenis kelamin, usia, alamat, kebiasaan merokok, jenis pekerjaan dan bentuk tubuh untuk menilai status IMT responden) serta food frequency questionnaire. Data yang telah terkumpul dilakukan analisis univariat, bivariat hingga multivariat dengan menggunakan uji regresi logistik ganda. 
HASIL

Tabel 1. Karakteristik Demografi Responden N=94

\begin{tabular}{|c|c|c|c|c|c|c|c|c|}
\hline \multirow[t]{2}{*}{ Demografi } & \multicolumn{3}{|c|}{$\begin{array}{l}\text { Kelompok Kasus } \\
\text { Rheumatoid Arthritis }\end{array}$} & \multicolumn{3}{|c|}{$\begin{array}{c}\text { Kelompok Kontrol } \\
\text { Non-Rheumatoid } \\
\text { Arthritis }\end{array}$} & \multirow[t]{2}{*}{$p$-value } & \multirow[t]{2}{*}{ OR (CI 95\%) } \\
\hline & $\mathrm{n}$ & $\%$ & $M \pm S D$ & $\mathrm{n}$ & $\%$ & $M \pm S D$ & & \\
\hline Usia (Tahun)(Rentang) & & & $\begin{array}{c}(60-73) \\
64.91 \pm 3.40\end{array}$ & & & $\begin{array}{c}(60-75) \\
63.46 \pm 3.35\end{array}$ & 0.012 & $2.51(1.38-8.48)$ \\
\hline $\begin{array}{l}\text { Jenis Kelamin: } \\
\text { Laki-laki } \\
\text { Perempuan }\end{array}$ & $\begin{array}{l}12 \\
35\end{array}$ & $\begin{array}{l}25 \\
75\end{array}$ & & $\begin{array}{c}7 \\
40\end{array}$ & $\begin{array}{l}15 \\
85\end{array}$ & & 0.014 & $3.20(3.31-7.03)$ \\
\hline $\begin{array}{l}\text { Pekerjaan: } \\
\text { Tidak Berisiko } \\
\text { Berisiko }\end{array}$ & $\begin{array}{c}9 \\
38\end{array}$ & $\begin{array}{l}19.1 \\
80.9\end{array}$ & & $\begin{array}{l}29 \\
18\end{array}$ & $\begin{array}{l}61.7 \\
38.3\end{array}$ & & 0.000 & $6.80(2.67-17.32)$ \\
\hline $\begin{array}{l}\text { Status Ekonomi } \\
\geq U M K \\
<\text { UMK }\end{array}$ & $\begin{array}{l}17 \\
30\end{array}$ & $\begin{array}{l}36.2 \\
63.8\end{array}$ & & $\begin{array}{l}17 \\
30\end{array}$ & $\begin{array}{l}36.2 \\
63.8\end{array}$ & & 0.062 & $4.75(2.14-6.25)$ \\
\hline $\begin{array}{l}\text { Riwayat Merokok } \\
\text { (Tahun)(Rentang) }\end{array}$ & & & $\begin{array}{c}(35-58) \\
48.04 \pm 7.07\end{array}$ & & & $\begin{array}{c}(40-59) \\
51.34 \pm 6.39\end{array}$ & 0.042 & $2.86(1.12-7.27)$ \\
\hline $\begin{array}{l}\text { Diet (Kadar Purin) } \\
\text { Normal } \\
\text { Tinggi Purin }\end{array}$ & $\begin{array}{c}8 \\
39\end{array}$ & $\begin{array}{l}17.0 \\
83.0\end{array}$ & & $\begin{array}{l}20 \\
27\end{array}$ & $\begin{array}{l}42.6 \\
57.4\end{array}$ & & 0.013 & $3.61(1.38-9.38)$ \\
\hline $\begin{array}{l}\text { Obesitas } \\
\text { Tidak mengalami } \\
\text { Obesitas }\end{array}$ & $\begin{array}{l}10 \\
37\end{array}$ & $\begin{array}{l}21.3 \\
78.7\end{array}$ & & $\begin{array}{l}22 \\
25\end{array}$ & $\begin{array}{l}46.8 \\
53.2\end{array}$ & & 0.017 & $3.25(1.31-8.03)$ \\
\hline
\end{tabular}

${ }^{*} p<0,05$, paired t-test

Berdasarkan Tabel 1 di atas dapat dilihat bahwa pada kelompok kasus status ekonomi terbanyak adalah $<$ UMK (83\%), sebagian besar responden tidak merokok (59.6\%), sebagian besar diet tinggi purin (83.6\%), kasus sebagian besar pekerjaan responden adalah berisiko $(80.9 \%)$, dan sebagian besar responden mengalami obesitas (78.7\%). Pada kelompok kontrol status ekonomi terbanyak adalah<UMK (63.8\%), sebagian besar responden tidak merokok (80.9\%), sebagian besar diet responden juga tinggi purin (57.4\%), sebagian besar pekerjaan responden adalah tidak berisiko $(61.7 \%)$ dan sebagian besar responden juga mengalami obesitas $(53.2 \%)$.

\section{Status ekonomi dengan kejadian RA pada lansia}

Secara statistik hasil penelitian didapatkan nilai $P$-value $=0.062$ hal tersebut menunjukkan tidak ada hubungan yang signifikan antara status ekonomi dengan kejadian RA pada lansia. Penelitian ini berbanding terbalik dengan penelitian yang dilakukan di Swedia yang menyatakan bahwa terdapat hubungan antara faktor sosial ekonomi dengan RA (Hochberg et al., 2011).

Sosial ekonomi adalah keadaan atau kemampuan lansia dalam memenuhi kebutuhannya untuk mencapai kemakmuran dan kesejahteraan, Status sosial ekonomi juga sangat dipengaruhi oleh tingkat pendapatan

Athaya Hafizhah"* RSUD H. Abdul Manap Kota Jambi. *Email: thaya.fizha@gmail.com Umi Romayati Keswara ${ }^{2}$ Program Studi Diploma III Keperawatan Universitas Malahayati Dhiny Easter Yanti ${ }^{3}$ Fakultas Kesehatan Masyarakat Universitas Malahayati 
keluarga (Soekanto, \& Sulistyowati, 2017). Semakin tinggi penghasilan keluarga, maka akan meningkatkan daya beli, sehingga penyediaan pangan dalam keluarga akan semakin meningkat.

Hasil penelitian ini didapatkan 8 responden yang memiliki penghasilan $\geq$ UMK tetapi mengalami RA. Responden dengan penghasilan $\geq$ UMK memiliki gaya hidup yang kurang baik seperti cenderung membelanjakan uangnya dan mengalokasikan waktunya kepada berbagai hal yang tidak mendukung terwujudnya status kesehatan yang baik yang akhirnya akan berdampak pada disabilitas seperti adanya nyeri dan ketidakmampuan, kehilangan fungsi, atau keterbatasan aktifitas. Selain itu, responden yang memiliki penghasilan $\geq$ UMK juga memiliki faktor-faktor lain yang dapat meningkatkan risiko penyakit RA seperti diet tinggi purin, obesitas dan pekerjaan berisiko.

Tabel 2 Hasil Uji Multivariat Faktor-Faktor Yang Berhubungan Dengan Kejadian RA Pada Lansia N=94

\begin{tabular}{lcccccc}
\hline \multicolumn{1}{c}{ Variabel } & B & S.E & P-Value & OR & \multicolumn{2}{c}{ 95\% C.I For Exp (B) } \\
\cline { 6 - 7 } & & & & Adjusted & Lower & Upper \\
\hline Merokok & 1.697 & 0.613 & 0.006 & 5.456 & 1.642 & 18.131 \\
Diet & 1.895 & 0.633 & 0.003 & 6.653 & 1.924 & 23.008 \\
Pekerjaan & 2.057 & 0.569 & 0.000 & 7.826 & 2.567 & 23.854 \\
Obesitas & 1.897 & 0.647 & 0.003 & 6.669 & 1.875 & 23.722 \\
Constan & -4.468 & 1.044 & 0.000 & 0.011 & &
\end{tabular}

Berdasarkan Tabel 2 dapat diketahui bahwa semua variabel memiliki $p$-value $<0,05$. Variabel pekerjaan memiliki $p$ - value $(0,000)$ dengan nilai $\mathrm{OR}=7.826$ lebih besar dibandingkan dengan variabel yang lain dengan tingkat kepercayaan diantara 2.56 - 23.85, maka dapat disimpulkan bahwa pekerjaan merupakan variabel dominan terhadap kejadian RA.

Hasil penelitian menunjukkan bahwa 38 responden yang mengalami RA dan memiliki pekerjaan yang berisiko, sebanyak 11 responden adalah petani, 15 responden ibu rumah tangga tanpa pembantu, 5 responden sopir, dan 7 responden bekerja sebagai buruh. Data tersebut menunjukkan bahwa ibu rumah tangga tanpa pembantu dan petani merupakan pekerjaan berisiko terbanyak pada lansia penderita RA.

\section{PEMBAHASAN}

\section{Analisis hubungan perilaku merokok dengan} kejadian RA pada lansia

Hasil penelitian didapatkan nilai $P$-value $=$ 0.042 , hal tersebut menunjukkan ada hubungan yang signifikan antara perilaku merokok dengan kejadian $\mathrm{RA}$ dan nilai $\mathrm{OR}=2.86$ yang menunjukkan bahwa responden yang merokok berisiko 2.86 kali mengalami kejadian RA dibanding responden yang tidak merokok. Hasil penelitian ini sejalan dengan penelitian Hutchinson , et al (2001) di Inggris dengan menggunakan analisis regresi logistik mendapatkan ada hubungan yang mencolok antara perokok berat dan RA.

Sejumlah studi cohort dan case-control menunjukkan bahwa rokok tembakau berhubungan dengan peningkatan risiko RA. Merokok berhubungan dengan produksi dari rheumatoid factor (RF) yang akan berkembang setelah 10 hingga 20 tahun. Merokok juga berhubungan dengan gen ACPA-positif RA dimana perokok menjadi 10 hingga 40 kali lebih tinggi dibandingkan bukan perokok.

Pada hasil penelitian ini juga ditemukan sebanyak 28 responden memiliki kebiasaan tidak merokok tetapi mengalami RA. Hal ini berkaitan erat dengan faktor risiko RA lainnya yang dimiliki responden seperti diet tinggi purin, pekerjaan berisiko, dan obesitas.

\section{Analisis hubungan diet dengan kejadian RA pada lansia}

Hasil penelitian didapatkan nilai $\mathrm{P}$-value $=$ 0.013 , hal tersebut menunjukkan ada hubungan yang signifikan antara diet dengan kejadian RA dan nilai $\mathrm{OR}=3.61$ yang menunjukkan bahwa responden dengan diet tinggi purin berisiko 3.61 kali mengalami kejadian RA dibanding responden dengan diet normal. Hasil penelitian ini sejalan dengan penelitian Ahdaniar, Hasanuddin, \& Indar. (2014) di Wilayah Puskesmas Kassi-Kassi Kota Makassar, hasil uji statistik diperoleh nilai $p$-value $=$ 0.012 . Penelitian di atas sejalan dengan penelitian sebelumnya yang menyatakan bahwa ada

\footnotetext{
Athaya Hafizhah"* RSUD H. Abdul Manap Kota Jambi. *Email: thaya.fizha@gmail.com

Umi Romayati Keswara ${ }^{2}$ Program Studi Diploma III Keperawatan Universitas Malahayati

Dhiny Easter Yanti ${ }^{3}$ Fakultas Kesehatan Masyarakat Universitas Malahayati
} 
hubungan antara diet dan inflamasi pada RA (Ahdaniar, Hasanuddin, \& Indar, 2014; Symmons, 2003).

Makanan yang dapat menyebabkan RA adalah makanan dengan kandungan tinggi protein antara lain daging merah seperti kambing, sapi, kuda dan lain-lain, kacang-kacangan seperti kacang kedelai, kacang tanah, kacang merah, kacang hijau dan tauge. Makanan yang tinggi protein akan menghasilkan tinggi purin, sehingga akan meningkatkan kadar asam urat di dalam darah sebagai hasil akhir dari pemecahan purin. Oleh karena itu pola makan yang salah menjadi salah satu pencetus terjadinya RA dan kekambuhan.

Pengaturan makanan merupakan hal yang sangat penting karena dengan penyakit yang diderita pasien harus mengkonsumsi makanan dengan kandungan purin rendah. Pola makan yang sehat sebaiknya dimulai dengan mengadakan perubahan-perubahan kecil pada makanan yang kita pilih, juga mengurangi makanan yang dapat mempengaruhi kekambuhan (Bawarodi, Rottie, \& Malara, 2017). Berdasarkan uraian di atas peneliti menyimpulkan konsumsi makanan tinggi purin dapat meningkatkan risiko penyakit RA.

\section{Analisis hubungan pekerjaan dengan kejadian RA pada lansia}

Hasil penelitian didapatkan nilai $\mathrm{P}$-value $=$ 0.000 , hal tersebut menunjukkan ada hubungan yang signifikan antara pekerjaan dengan kejadian $\mathrm{RA}$ dan didapatkan nilai $\mathrm{OR}=6.80$ yang menunjukkan bahwa responden yang memiliki perkerjaan berisiko tinggi, berisiko 6.80 kali mengalami kejadian RA dibanding responden yang memiliki pekerjaan tidak berisiko.

Hasil penelitian di atas sejalan dengan penelitian di Swedia dimana pekerjaan dievaluasi melalui analisis bertingkat dan multivariate memperoleh hasil bahwa pekerjaan berisiko dalam pengembangan penyakit RA, seperti dengan diperoleh rasio odds logistik (LOR) yang meningkat secara signifikan terlihat untuk pria konduktor, pekerja angkutan dan transportasi (LOR 17.8, 95\% Cl 1.5 hingga 207.8 dan LOR 4.7, 95\% Cl 1.4 hingga16,3, masing-masing), dan petani dan pekerja pertanian (LOR $2.4,95 \% \mathrm{Cl} 1.1$ hingga 5.2, dan LOR 2.2, 95\% Cl 1.3 hingga 3.5, masingmasing). Hasil penelitian di atas dibuktikan juga oleh penelitian di Indonesia yang menyebutkan bahwa pekerjaan buruh, petani, nelayan dan lainnya mempunyai risiko rematik dua kali dibandingkan dengan responden yang masih bersekolah (Olsson, Skogh, Axelson, \& Wingren, 2004; Nainggolan, 2009).

Pekerjaan adalah salah satu dari faktor yang dapat memicu timbulnya penyakit pada sendi. Aktivitas dengan beban yang berat serta daya tekanan yang dapat memperberat sendi dan pekerjaan yang banyak menggunakan tangan dan kaki dalam waktu yang lama akan muncul keluhan yang dirasakan pada penderita RA.

\section{Analisis hubungan obesitas dengan kejadian RA pada lansia}

Berdasarkan Tabel 2 di atas, secara statistik hasil penelitian didapatkan nilai $\mathrm{P}$-value $=0.017$ dimana kurang dari nilai kemaknaan yaitu $5 \%$ (0.05), hal tersebut menunjukkan ada hubungan yang signifikan antara obesitas dengan kejadian $\mathrm{RA}$ dan didapatkan nilai $\mathrm{OR}=3.25$ yang menunjukkan bahwa responden yang mengalami obesitas berisiko 3.25 kali mengalami kejadian RA dibanding responden yang tidak mengalami obesitas. Hasil penelitian di atas sejalan dengan penelitian sebelumnya yang berjudul Blood Transfusion, Smoking, And Obesity As Risk Factors For The Development Of Rheumatoid arthritis di Amerika dengan menggunakan studi Case control diperoleh hasil RA memiliki sejumlah faktor risiko yang potensial termasuk obesitas (Symmons, Bankhead, Harrison, Brennan, Silman, Barrett, \& Scott, 1997).

Obesitas ditimbulkan oleh kelebihan nutrisi dan resistensi insulin, terkait erat dengan kelebihan produksi sitokin pro inflamasi. Hal ini terlihat pada inflamasi kronik. Gizi berlebih menghasilkan reaktif oksigen spesies dalam jumlah banyak, sehingga terjadi stres oksidasi yang merusak sek dan memicu respon inflamasi. Seiring dengan resisitensi insulin yang berlangsung, proses inflamsi juga meningkat. Dapat dikatakan bahwa asupan nutrisi yang berlebih bisa menimbulkan obesitas dan resistensi insulin yang akan memicu stress oksidasi dan respon inflamasi yang akan meningkatkan risiko RA (Wolhurter, 2010).

Peneliti menyimpulkan bahwa uraian di atas membuktikan bahwa RA dapat disebabkan oleh berat badan berlebih atau obesitas.

\footnotetext{
Athaya Hafizhah"* RSUD H. Abdul Manap Kota Jambi. *Email: thaya.fizha@gmail.com

Umi Romayati Keswara ${ }^{2}$ Program Studi Diploma IIl Keperawatan Universitas Malahayati

Dhiny Easter Yanti ${ }^{3}$ Fakultas Kesehatan Masyarakat Universitas Malahayati
} 


\section{Analisis Multivariat}

Menurut peneliti ibu rumah tangga tanpa pembantu lebih banyak bekerja tanpa mengenal batas waktu, dan pekerjaan yang dilakukan cenderung berulang (monoton) sehingga ibu rumah tangga cenderung menjadi lebih cepat bosan dan rentan mengalami stress. Hasil studi sebelumnya didapatkan bahwa ada hubungan antara stress psikologis dengan tingkat keparahan rheumatoid arthritis (Hassett, \& Clauw, 2010). Mekanisme yang diduga mendasari hubungan ini termasuk perubahan fungsi sistem otonom, neuroendokrin dan kekebalan tubuh. Selain itu, pekerjaan ibu rumah tangga dilakukan di dalam rumah dan kurang terpapar sinar matahari.

Hal ini berdampak pada kurangnya asupan vitamin $D$ yang didapat dari paparan sinar UV-B secara langsung. UV-B merupakan faktor utama untuk sintesis vitamin $D$ dalam tubuh yang meregulasi pertumbuhan dan diferensiasi sel yang berpengaruh dalam mengatur kekebalan tubuh dan bertindak sebagai agen imunosupresif. Sintesis vitamin $D$ juga telah terbukti memiliki sifat yang dapat menekan autoimunitas melalui peningkatan pengaturan sel Th2 dan sel T-regulator (Arkema et al, 2013). Sehingga menurut peneliti, produksi vitamin $D$ yang cukup dapat menurunkan risiko penyakit RA.

Pekerjaan terbanyak lainnya adalah petani dengan jumlah 11 responden. Pekerjaan petani berhubungan erat dengan paparan zat kimia seperti pupuk, dan pestisida secara terus-menerus yang dapat masuk ke dalam tubuh melalui pernapasan. Paparan zat kimia ini dapat menjadi risiko penyakit RA. Studi toksikologi menunjukkan hubungan yang kompleks mengingat keragaman efek pestisida pada system imun. Pestisida dapat berdampak pada diferensiasi dan regulasi imun adapatif dan bawaan, yang mengarah ke penekanan kekebalan akut dan kronis, penurunan respon terhadap infeksi, peradangan dan autoimunitas (Parks et al, 2011). Paparan aerosol pada petani dapat dikaitkan dengan agen yang aktif secara biologis dalam partikel debu itu sendiri atau dengan kontaminasi debu, misalnya bakteri gram-negatif yang dapat menyebabkan pelepasan sitokin seluler yang dimediasi endotoksin, aktivasi makrofag, dan limfosit yang menghasilkan inflamasi lokal dan reaksi sistemik (Olsson et al, 2000).
Sehingga menurut peneliti paparan pestisida secara terus-menerus dan kontaminasi debu pada petani dapat meningkatkan risiko penyakit RA.

\section{SIMPULAN}

Responden usia termuda 60 tahun $(5.3 \%)$ dan tertua 75 tahun (1.1\%). Sebagian besar responden berjenis kelamin perempuan $(79.8 \%)$, status ekonomi < UMK (73.4\%), tidak merokok (70.2\%),kebiasaan makan tinggi purin(70.2\%), memiliki pekerjaan berisiko (59.6\%), mengalami obesitas $(66.0 \%)$.

Tidak ada hubungan antara status ekonomi dengan kejadian RA ( $p$ - value 0.062).Ada hubungan antara merokok ( $p-$ value 0.042$)$, diet $(p$ - value 0.013$)$, pekerjaan ( $p$ - value 0.000$)$, dan obesitas $(p$ - value 0.017$)$ dengan kejadian RA pada lansia di poliklinik rawat jalan RSPBA Kota Bandar Lampung Tahun 2019. Variabel yang paling dominan yang berhubungan dengan kejadian RA adalah pekerjaan $(\mathrm{OR}=7.826)$.

\section{SARAN}

Bagi lansia dengan penyakit RA yang memiliki faktor risiko pekerjaan berisiko sebaiknya mengurangi paparan zat-zat yang dapat memperberat penyakit RA (debu, pestisida, dsb) dengan menggunakan alat pelindung diri, dan menyediakan waktu untuk melakukan aktifitas fisik di luar ruangan yang menyenangkan sehingga dapat mengurangi stress dan membantu penyerapan vit.D dalam tubuh lebih maksimal.Bagi peneliti selanjutnya agar memperluas lokasi penelitian, dan mengembangkan variabel penelitian ini seperti faktor genetik, kadar vit.D, faktor stress psikososial, dan jenis pekerjaan lainnya agar hasil penelitian yang didapatkan lebih akurat.

\section{DAFTAR PUSTAKA}

Ahdaniar, A., Hasanuddin, H., \& Indar, I. (2014). Faktor yang berhubungan dengan kejadian penyakit rematik pada lansia di wilayah puskesmas kassi-kassi kota Makassar. Jurnal IImiah kesehatan diagnosis, 4(2), 150-156.

\footnotetext{
Athaya Hafizhah" ${ }^{1 *}$ RSUD H. Abdul Manap Kota Jambi. ${ }^{*}$ Email: thaya.fizha@gmail.com

Umi Romayati Keswara ${ }^{2}$ Program Studi Diploma IIl Keperawatan Universitas Malahayati

Dhiny Easter Yanti ${ }^{3}$ Fakultas Kesehatan Masyarakat Universitas Malahayati
} 
Arkema, E. V., Hart, J. E., Bertrand, K. A., Laden, F., Grodstein, F., Rosner, B. A., \& Costenbader, K. H. (2013). Exposure to ultraviolet-B and risk of developing rheumatoid arthritis among women in the Nurses' Health Study. Annals of the rheumatic diseases, 72(4), 506-511

Bawarodi, F., Rottie, J., \& Malara, R. T. (2017). Faktor-faktor yang Berhubungan dengan Kekambuhan Penyakit Rematik di Wilayah Puskesmas Beo Kabupaten Talaud. Jurnal Keperawatan, 5(1).

Bykerk, V. P., Akhavan, P., Hazlewood, G. S., Schieir, O., Dooley, A., Haraoui, B., \& Pencharz, J. (2012). Canadian Rheumatology Association recommendations for pharmacological management of rheumatoid arthritis with traditional and biologic diseasemodifying antirheumatic drugs. The Journal of rheumatology, 39(8), 1559-1582

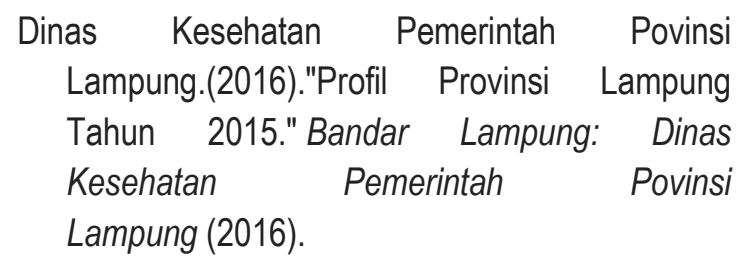

Firestein, G. S., Budd, R., Gabriel, S. E., Mclnnes, I. B., \& O'Dell, J. R. (2016). Kelley and Firestein's Textbook of Rheumatology E-Book. Elsevier Health Sciences

Hassett, A. L., \& Clauw, D. J. (2010). The role of stress in rheumatic diseases

Hochberg, M. C., Silman, A. J., Smolen, J. E., Weinblatt, M. E., \& Weisman, M. H. (2011). Rheumatology(Fifth). Philadelpia: Elsevier.
Hutchinson, D., Shepstone, L., Moots, R., Lear, J. T., \& Lynch, M. P. (2001). Heavy cigarette smoking is strongly associated with rheumatoid arthritis (RA), particularly in patients without a family history of RA. Annals of the rheumatic diseases, 60(3), 223-227.

Nainggolan, O. (2009). Prevalensi dan determinan penyakit rematik di Indonesia. Majalah Kedokteran Indonesia, 59(12), 588-594.

Olsson, Å. R., Skogh, T., \& Wingren, G. (2000). Occupational determinants for rheumatoid arthritis. Scandinavian Journal of Work, Environment and Health, 26(3)

Olsson, Å. R., Skogh, T., Axelson, O., \& Wingren, G. (2004). Occupations and exposures in the work environment as determinants for rheumatoid arthritis. Occupational and environmental medicine, 61(3), 233-238.

Parks, C. G., Walitt, B. T., Pettinger, M., Chen, J. C., De Roos, A. J., Hunt, J., \& Howard, B. V. (2011). Insecticide use and risk of rheumatoid arthritis and systemic lupus erythematosus in the Women's Health Initiative Observational Study. Arthritis care \& research, 63(2), 184-194

Perhimpunan Reumatologi Indonesia. (2014). Diagnosis dan Pengelolaan Artritis Reumatoid

Singh, J. A., Saag, K. G., Bridges Jr, S. L., Akl, E. A., Bannuru, R. R., Sullivan, M. C., ... \& Curtis, J. R. (2016). 2015 American College of Rheumatology guideline for the treatment of rheumatoid arthritis. Arthritis \& rheumatology, 68(1), 1-26

Soekanto, S., \& Sulistyowati, B. (2017). Sosiologi Suatu Pengantar (Edisi Revi). Jakarta: Rajawali Pers.

\footnotetext{
Athaya Hafizhah"* RSUD H. Abdul Manap Kota Jambi. *Email: thaya.fizha@gmail.com Umi Romayati Keswara ${ }^{2}$ Program Studi Diploma 111 Keperawatan Universitas Malahayati Dhiny Easter Yanti ${ }^{3}$ Fakultas Kesehatan Masyarakat Universitas Malahayati
} 
Symmons, D. P. (2003). Environmental factors and the outcome of rheumatoid arthritis. Best practice \& research Clinical rheumatology, 17(5), 717-727.

Symmons, D. P., Bankhead, C. R., Harrison, B. J., Brennan, P., Silman, A. J., Barrett, E. M., \& Scott, D. G. (1997). Blood transfusion, smoking, and obesity as risk factors for the development of rheumatoid arthritis. Results from a primary care-based incident case-control study in Norfolk, England. Arthritis \& Rheumatism: Official Journal of the American College of Rheumatology, 40(11), 1955-1961.
Tobón, G. J., Youinou, P., \& Saraux, A. (2010). The environment, geo-epidemiology, and autoimmune disease: Rheumatoid arthritis. Autoimmunity reviews, 9(5), A288A292

Wolhurter, T. (2010). Nutritional management of osteoarthritis. Medical Chronicle, 27. 